\title{
Physiological characterization of maize tolerance to low dose of aluminum, highlighted by promoted leaf growth
}

\author{
Liang Wang ${ }^{1}$ - Xian-Wei Fan ${ }^{1} \cdot$ Jian-Long Pan ${ }^{1} \cdot$ Zhang-Bao Huang $^{1} \cdot$ \\ You-Zhi Li ${ }^{1}$
}

Received: 9 March 2015/Accepted: 17 July 2015/Published online: 8 August 2015

(c) The Author(s) 2015. This article is published with open access at Springerlink.com

\begin{abstract}
Main conclusion Effects of a low aluminum (Al) dose were characterized. The Al supplement inhibited root growth but enhanced leaf growth in maize lines with different Al sensitivities.

High levels of $\mathrm{Al}$ are phytotoxic especially in acidic soils. The beneficial effects of low Al levels have been reported in some plant species, but not in maize. Maize is relatively more sensitive to Al toxicity than other cereals. Seedlings, at the three leaf stage, of four Chinese maize foundation parent inbred lines with different Al tolerances, were exposed to complete Hoagland's nutrient solution at $\mathrm{pH} 4.5$ supplemented with $48 \mu \mathrm{M} \mathrm{Al}^{3+}$ under controlled growth conditions, and then the $\mathrm{Al}$ stress (AS) was removed. The leaf and root growth, root cell viability, superoxide dismutase (SOD), peroxidase (POD), catalase (CAT), ions $\left(\mathrm{K}^{+}, \mathrm{Ca}^{++}\right.$and $\left.\mathrm{Mg}^{++}\right)$, photosynthetic rate and chlorophyll, protein and malondialdehyde contents in tissues were assayed. In conclusion, a low $\mathrm{Al}$ dose inhibits root growth but enhances leaf growth in maize. The Al-promoted leaf growth is likely a result of increased protein synthesis, a lowered $\mathrm{Ca}^{++}$level, and the discharge of the growth-inhibitory factors. The Al-promoted leaf growth may be a 'memory' effect caused by the earlier AS in
\end{abstract}

L. Wang and X.-W. Fan contributed equally to this work.

You-Zhi Li

dyzl@gxu.edu.cn

1 State Key Laboratory for Conservation and Utilization of Subtropical Agro-bioresources, Key Laboratory of Ministry of Education for Microbial and Plant Genetic Engineering, College of Life Science and Technology, Guangxi University, 100 Daxue Road, Nanning 530004, Guangxi, People's Republic of China maize. $\mathrm{Al}$ causes cell wall rupture, and a loss of $\mathrm{K}^{+}, \mathrm{Ca}^{++}$ and $\mathrm{Mg}^{++}$from root cells. CAT is an auxiliary antioxidant enzyme that works selectively with either SOD or POD against AS-related peroxidation, depending on the maize tissue. CAT is a major antioxidant enzyme responsible for root growth, but SOD is important for leaf growth during AS and after its removal. Our results contribute to understanding how low levels of $\mathrm{Al}$ affect maize and $\mathrm{Al}$-resistant mechanisms in maize.

Keywords Acidic soils - Aluminum toxicity - Aluminum benefit $\cdot$ Maize $\cdot$ Root

$\begin{array}{ll}\text { Abbreviations } \\ \text { AS } & \text { Al stress } \\ \text { CAT } & \text { Catalase } \\ \text { MDA } & \text { Malondialdehyde } \\ \text { POD } & \text { Peroxidase } \\ \text { RAS } & \text { Removal of AS } \\ \text { ROS } & \text { Reactive oxygen species } \\ \text { SOD } & \text { Superoxide dismutase } \\ \text { SOR } & \text { Superoxide radicals }\end{array}$

\section{Introduction}

Aluminum ( $\mathrm{Al}$ ) is the third most abundant chemical element in the earth's crust (Pilon-Smits et al. 2009). It is phytotoxic, especially in acidic soils with a $\mathrm{pH}$ in the 4.5-5.0 range (Matsumoto 2000). The acidic soils account for $\sim 50 \%$ of the world's cultivable area (Panda et al. 2009). The phytotoxicity of Al has been studied extensively in organs, tissues, and cells (Kochian 1995; Ma 
2000; Sivaguru et al. 2000; Mossor-Pietraszewska 2001; Čiamporová 2002; Ma and Furukawa 2003; Chen 2006; Illéš et al. 2006; Poschenrieder et al. 2008; Giannakoula et al. 2010; Inostroza-Blancheteau et al. 2012). Most studies focused on the inhibition of root growth (Chen 2006; He et al. 2014), and changes in root architecture and elongation under Al stress (AS) (Pilon-Smits et al. 2009). As with other abiotic stresses, AS can result in peroxidation by triggering a greater production of reactive oxygen species (ROS). To detoxify AS-caused ROS, plants employ enzymatic antioxidants, majorly including superoxide dismutases (SOD), peroxidases (POD) and catalases (CAT) (Boscolo et al. 2003; Inostroza-Blancheteau et al. 2012). However, whether these three enzymes equally contribute or selectively cooperate during the detoxification of AScaused ROS remains unknown.

A few reports have indicated that low or moderate doses of Al have beneficial effects on some plant species, such as Miscanthus sinensis (Yoshii 1937), tea plant (Ghanati et al. 2005), and Melastoma malabathricum (Watanabe et al. 2005, 2006). Some crops also benefit from $\mathrm{Al}$, such as rice (Oryza sativa) (Osaki et al. 1997), triticale (Zhang et al. 1999, 2007) and alfalfa (Zhang et al. 1999, 2007), and soybean (Du et al. 2010).

Maize (Zea mays L.) is relatively more sensitive to $\mathrm{Al}$ toxicity than other cereals (Doncheva et al. 2005; Poschenrieder et al. 2008). Maize responses to AS have been investigated, but the results have been varied (Boscolo et al. 2003; Giannakoula et al. 2008, 2010; Mihailovic et al. 2008). In soybean, a high level of AS caused plasmolysis, cell wall rupture, and the leakage of cellular contents ( $\mathrm{Yu}$ et al. 2011). However, apparently no more attention was paid to AS effects on maize cells and their growth. Interestingly, it may be possible to mitigate soil $\mathrm{Al}$ toxicity using appropriate methods, such as the application of dolomite (Holmström et al. 2005). This raises the question of whether maize subjected to AS could resume its growth after the removal of AS (RAS).

We characterize the maize responses to AS and RAS at organ, tissue, physiological, and cellular levels in four Chinese maize foundation parent inbred lines (two Alsensitive lines, and two relatively Al-tolerant lines).

\section{Materials and methods}

\section{Maize inbred lines and growth conditions}

The maize inbred lines used were Huangzao4 (H4), Chang7-2 (C7-2), Ye478 (Y478) and Zheng58 (Z58), of which $\mathrm{H} 4$ and $\mathrm{C} 7-2$ are more sensitive to AS relative to Y478 and Z58. The maize seeds were kindly supplied by Professor Yu Li of the Institute of Crop Sciences, CAAS.
The seeds were surface sterilized by soaking for $12 \mathrm{~h}$ at $28{ }^{\circ} \mathrm{C}$ in distilled water, and then for $6 \mathrm{~min}$ in $75 \%$ ethanol. The surface-sterilized seeds were grown at $28{ }^{\circ} \mathrm{C}$ in fresh moist river sand. After emergence, seedlings with the same growth potential were selected and carefully transferred into holes in perforated polystyrene foam boards that were fixed $0.5 \mathrm{~cm}$ above the surface of the complete Hoagland's nutrient solution at $\mathrm{pH}$ 7. The nutrient solution was vigorously aerated for 15 min every $1 \mathrm{~h}$, adjusted daily to maintain the $\mathrm{pH}$ at $7 \pm 0.2$, and renewed every 3 days. When reached the three leaf stage, the seedlings were subjected to the AS treatment in the nutrient solution at $\mathrm{pH} 4.5$ supplemented with $\mathrm{AlCl}_{3} \cdot 7 \mathrm{H}_{2} \mathrm{O}$, where the active $\mathrm{Al}^{3+}$ concentration was $48 \mu \mathrm{M}$.

After a 72-h AS treatment, the seedlings were transferred and grown for $72 \mathrm{~h}$ at $28{ }^{\circ} \mathrm{C}$ in an $\mathrm{Al}$-free nutrient solution, representing RAS treatment. The seedling control treatment was performed using the $\mathrm{Al}$-free nutrient solution in parallel with the AS treatment. All of the seedlings were grown in a chamber with $60-80 \%$ humidity, a $12 \mathrm{~h}$ of light and a constant temperature of $28{ }^{\circ} \mathrm{C}$.

The tissues were sampled at 10 a.m. every $24 \mathrm{~h}$. The sampled tissues were directly used, immediately frozen in liquid nitrogen and then stored at $-80^{\circ} \mathrm{C}$, or immediately fixed in a solution containing 5 of $37 \%$ formalin, 90 of $70 \%$ alcohol and 5 of $37 \%$ glacial acetic acid (GAA), depending on the analysis requirements.

\section{Measurement of leaf and root growth rates}

The absolute length of primary roots from the root-stem transition zone to the root tip, and the absolute length of the third leaves from the petiole base to the apex were measured. For both, leaves and roots, growth was expressed as the relative growth rates, which were estimated by (the length under AS/the length under parallel Al-free control) $\times 100 \%$.

\section{Assay of tissue Al ion contents}

The Al contents in the tissues were assayed using the conventional S-chromium azure (SCA) chromogenic method. Briefly, the tissues were oven dried. A 0.1-g aliquots of the dried samples was digested for $24 \mathrm{~h}$ in $1.5 \mathrm{~mL}$ of $2 \mathrm{mM} \mathrm{HNO}_{3}$, and then diluted 20 times with deionized water. A $1-\mathrm{mL}$ aliquot of the dilution was transferred to a $25-\mathrm{mL}$ volumetric flask, and then $1 \mathrm{~mL} \mathrm{HNO}_{3}(0.1 \mathrm{M})$, $2 \mathrm{~mL}$ cetyltrimethylammonium bromide (CTAB $5 \mathrm{mM}$ ), $2 \mathrm{~mL}$ EDTA-Zn $(0.05 \mathrm{mM}), 2 \mathrm{~mL} \mathrm{SCA}(0.05 \%)$, and $4 \mathrm{~mL}$ six-methyl tetramine solution $(40 \%)$ were added in that order. Finally, the volume was adjusted to $25 \mathrm{~mL}$ volume by adding deionized water, and then sufficiently mixed. The flask was placed for $20 \mathrm{~min}$ at room 
temperature, and the optic density (OD) of the mixed solution at $635 \mathrm{~nm}$ was assayed. The resulting $\mathrm{OD}_{635}$ values were used to estimate the $\mathrm{Al}$ content in the tissues against a standard solution curve prepared with different $\mathrm{AlCl}_{3} \cdot 7 \mathrm{H}_{2} \mathrm{O}$ concentrations.

\section{Preparation of the plant tissue extract}

A 0.25 -g aliquot of the fresh tissues was homogenized by grinding in $5 \mathrm{~mL}$ pre-cooled phosphate buffer solution (PBS) at $\mathrm{pH} 7.4$ containing $1 \mathrm{mM}$ EDTA, and then centrifuged for $20 \mathrm{~min}$ at $16,200 \times g$ at $4{ }^{\circ} \mathrm{C}$. The resulting supernatant was stored at $-80{ }^{\circ} \mathrm{C}$.

\section{Assay of tissue total protein contents}

The total protein contents in the tissues were quantified according to the Coomassie Brilliant Blue-based method. In brief, a 1-mL aliquot of the protein extract was fully mixed with $1 \mathrm{~mL}$ G-250 Coomassie. Then, the $\mathrm{OD}_{620}$ value of the solution was assayed and used to estimate the protein content against the standard solution curve prepared with different calf serum concentrations.

\section{Assay of antioxidant enzyme activities}

The SOD activity was assayed following the methods described in Tang (1999) with some modifications. Briefly, the following solutions were added, in order, to a tuber: $1.5 \mathrm{~mL}$ of PBS at $\mathrm{pH} 7.4,0.3 \mathrm{~mL}$ of $130 \mathrm{mM}$ methionine, $0.3 \mathrm{~mL}$ of $750 \mu \mathrm{M}$ nitroblue tetrazolium (NTB), $0.3 \mathrm{~mL}$ of $110 \mu \mathrm{M}$ EDTA- $\mathrm{Na}_{2}, 0.3 \mathrm{~mL}$ of $110 \mu \mathrm{M}$ riboflavin, $0.1 \mathrm{~mL}$ of the plant tissue extract, and $0.5 \mathrm{~mL}$ deionized water. The solution mix was allowed to react for $20 \mathrm{~min}$ at a light intensity of 3000 lux at $25^{\circ} \mathrm{C}$, and the $\mathrm{OD}_{560}$ value of the mix was assayed. A SOD activity unit (U) was defined as a $50 \%$ inhibition of NTB photochemical reduction. The SOD activity was expressed as a specific activity of $U$ $\mathrm{mg}^{-1}$ protein.

POD activity was assayed as described in Tang (1999) with minor modifications. Briefly, a $20-\mu \mathrm{L}$ aliquot of the plant tissue extraction compound was added to, and well mixed with $3 \mathrm{~mL}$ PBS (pH 7.4) containing $1 \%$ (v/v) $\mathrm{H}_{2} \mathrm{O}_{2}$ and $5 \%(\mathrm{v} / \mathrm{v})$ guaiacol, and then the $\mathrm{OD}_{470}$ value was assayed. The POD activity $U$ was defined as an increase in the $\mathrm{OD}_{470}$ value of $0.01 \mathrm{~min}^{-1}$. The POD activity was determined as the specific activity of $\Delta \mathrm{A}_{470} \mathrm{~min}^{-1} \mathrm{mg}^{-1}$ protein.

CAT activity was assayed following the methods of Cakmak and Horst (1991) with some modifications. Briefly, a $100-\mu \mathrm{L}$ aliquot of the plant tissue extract was well mixed with $3 \mathrm{~mL}$ PBS (pH 7.4) containing $0.1 \mathrm{M}$ $\mathrm{H}_{2} \mathrm{O}_{2}$, and then its $\mathrm{OD}_{240}$ value was assayed. The CAT activity $\mathrm{U}$ was defined as a decrease in the $\mathrm{OD}_{240}$ value of $0.01 \mathrm{~min}^{-1}$.

\section{Assay of superoxide radicals (SORs)}

A $0.5-\mathrm{mL}$ aliquot of the plant tissue extract was well mixed with $0.5 \mathrm{~mL}$ PBS (pH 7.4) and $1 \mathrm{~mL}$ of $1 \mathrm{mM}$ hydroxylamine hydrochloride, and allowed to react for $1 \mathrm{~h}$ at $25{ }^{\circ} \mathrm{C}$. Then, $1 \mathrm{~mL}$ sulfanilic acid $(17 \mathrm{mM})$ and $1 \mathrm{~mL} \alpha$ naphthylamine $(7 \mathrm{mM})$ were added, and allowed to react for $20 \mathrm{~min}$ at $25^{\circ} \mathrm{C}$. The $\mathrm{OD}_{530}$ values of the reaction solution were then measured and used to estimate SOR values against a curve generated by the standard solution, which was made with the above-mentioned reaction solution supplemented with $\mathrm{NaNO}_{2}$, at $\mathrm{OD}_{530}$. The SOR production was expressed as $\mathrm{nM} \mathrm{min}{ }^{-1} \mathrm{mg}^{-1}$ protein.

\section{Assay of the malondialdehyde (MDA) content}

A 1-mL aliquot of the plant tissue extract was mixed with $2 \mathrm{~mL}$ solution containing $0.6 \%(\mathrm{~m} / \mathrm{v})$ thiobarbituric acid and $10 \%(\mathrm{~m} / \mathrm{v})$ trichloroacetic acid, reacted for $30 \mathrm{~min}$ in a boiling water bath, and immediately cooled on ice. The reaction solution was then centrifuged for $5 \mathrm{~min}$ at $11,600 \times g$. The $\mathrm{OD}_{532}$ and $\mathrm{OD}_{450}$ values of the resulting supernatant were measured, respectively. The MDA content was estimated using the formula of $\left[\left(6.45 \times \mathrm{OD}_{532}\right)\right.$ - $\left.\left(0.56 \times \mathrm{OD}_{450}\right)\right] \times$ plant tissue extraction compound (L)/the sample weight $(\mathrm{g})$.

\section{Evaluation of root cell viability}

The cell viability of fresh roots was evaluated as described previously (Tamás et al. 2006) with some modifications. The roots were rinsed for $5 \mathrm{~min}$ with deionized water to fully remove the residues on the surface, and then stained for $30 \mathrm{~min}$ in $0.25 \%(\mathrm{~m} / \mathrm{v})$ Evans blue. After staining, the roots were rinsed for $15 \mathrm{~min}$ with deionized water to fully remove the dye on the surface and then photographed.

\section{Microscopic observation of root tip cells}

The root tips $(0.5 \mathrm{~cm}$ long) from formalin-GAA-alcoholfixed roots were sectioned lengthwise using a paraffin slicing machine. The thickness of the slices was $6 \mu \mathrm{m}$. The resulting slices were stained for $15 \mathrm{~min}$ in a solution that was prepared with equal volume of the staining stock solution and $50 \%$ ethanol-GAA solution, where the staining stock solution was composed of $0.66 \mathrm{~g}$ hematoxylin, $3 \mathrm{~mL}$ GAA, $32 \mathrm{~mL}$ glycerol, $32 \mathrm{~mL}$ of $95 \%$ ethanol, $1.66 \mathrm{~g}$ aluminum potassium sulfate, and $33 \mathrm{~mL}$ deionized water. The stained slices were observed by light microscopy. 


\section{Assay of K, Ca, and Mg ions}

The tissues were fully oven dried. For each sample, a 0.1 -g aliquot of the dried tissues was used to measure $\mathrm{K}, \mathrm{Ca}$, and $\mathrm{Mg}$ ions in a 6400 atomic absorption spectrophotometer (Shanghai, China) following the conventional atomic absorption analysis method.

\section{Chlorophyll content assay}

A $0.5-\mathrm{g}$ aliquot of fresh leaves, the main veins of which were removed, was homogenized in $10 \mathrm{~mL}$ acetone. A 2-mL aliquot of the homogenate was centrifuged for $5 \mathrm{~min}$ at $2400 \times g$. The resulting supernatant was diluted five times with $80 \%$ acetone, and then measured for $\mathrm{OD}_{663}$ and $\mathrm{OD}_{645}$ values, respectively. The OD values were normalized against the OD value of $80 \%$ acetone, and then used to estimate the chlorophyll content based on the formula: the chlorophyll content $\left[\mathrm{mg} \mathrm{g}^{-1}\right.$ fresh weight $\left.(\mathrm{FW})\right]=$ $\left[\left(8.02 \times \mathrm{OD}_{663}+20.21 \times \mathrm{OD}_{645}\right) \times 10 \mathrm{~mL} \times 5\right] /(1000 \times$ $0.5)$.

\section{Measurement of the photosynthetic rate}

The photosynthetic rate measurements were taken at 9:00 a.m. on the middle part of the second leaves by using a Li6400 portable photosynthesis analyzer (Lincoln, NE, USA) under an artificial red and blue light source.

\section{Statistical analyses of the data}

The significant differences among the data were analyzed through one-way analysis of variance software, and the correlation analyses among the data were conducted based on the Pearson's correlation coefficient using the SPSS 13.0 software (http://www.spss.com/).

\section{Results}

\section{Maize growth}

No Al toxicity-related symptoms were found on the shoots of the tested maize seedlings (Fig. 1a-d). However, the root growth rate was significantly reduced under AS (Fig. 1e). Unexpectedly, the leaf growth rate in all of the maize lines was accelerated under AS, starting at $24 \mathrm{~h}$ after AS and increasing more significantly with the duration of AS (Fig. 1f).

After RAS, the roots of the seedlings of the AS-treated maize lines grew in a significantly increased way although the growth rate was still slower than that of the respective control lines (Fig. 1e). Interestingly, the leaves of the AStreated maize lines had higher growth rates than the respective Al-free controls even after RAS treatment, especially in $\mathrm{H} 4$ and $\mathrm{Z} 58$ lines (Fig. 1f).

\section{Al ion content}

The $\mathrm{Al}$ ion content was much higher in the roots and leaves of the stressed lines under AS than in the respective Al-free controls (Fig. 1g, h). After RAS, the Al content decreased significantly in all of the AS-treated roots (Fig. 1g) and slightly in the stressed leaves (Fig. 1h), when compared with those at the 72-h AS time point.

\section{SOD activity}

The SOD activity levels in the roots of the AS-treated maize lines started to significantly decrease $24 \mathrm{~h}$ after AS, remained almost unchanged $48 \mathrm{~h}$ after AS, and then sharply dropped $72 \mathrm{~h}$ after AS, while the activity levels in the roots of the control maize lines did not obviously change (Fig. 2a). The SOD activity levels in the leaves of the AStreated maize lines were approximate to those in the respective controls for $48 \mathrm{~h}$, but significantly decreased $72 \mathrm{~h}$ after AS (Fig. 2b).

The SOD activity levels in the roots of the stressed maize lines at $72 \mathrm{~h}$ post AS were obviously increased by RAS (Fig. 2a). However, only the activity in the roots of the AS-treated $\mathrm{H} 4$ line reached the level of the corresponding control roots (Fig. 2a). Overall, the SOD activity levels in the leaves of the AS-treated maize lines did recover to levels of respective control leaves after RAS treatment (Fig. 2b).

\section{Change in POD activity}

The POD activity levels in the roots of the AS-treated C7-2 and Y478 lines were almost constant within $48 \mathrm{~h}$ after AS but increased slightly in the roots of the AS-treated $\mathrm{H} 4$ and Z58 lines at $24 \mathrm{~h}$ after AS. However, the activity levels in the roots of the AS-treated maize lines significantly decreased $72 \mathrm{~h}$ after AS when compared with the activity levels in respective control roots (Fig. 2c). In contrast, the POD activity levels in the leaves of the AS-treated maize lines started to significantly decrease early at $24 \mathrm{~h}$ after AS, and then sluggishly declined with AS when compared with the activity levels in respective control leaves (Fig. 2d).

After $48 \mathrm{~h}$ of RAS treatment, the POD activity levels in the roots of the AS-treated maize lines almost reached the activity levels in the respective control roots (Fig. 2c). The POD activity levels in the leaves of AS-treated H4, C7-2 and Y478 lines indeed increased but did not reach the activity levels of the respective control leaves (Fig. 2d). Only the activity level in the leaves of AS-treated Z58 line reached to control level (Fig. 2d). 


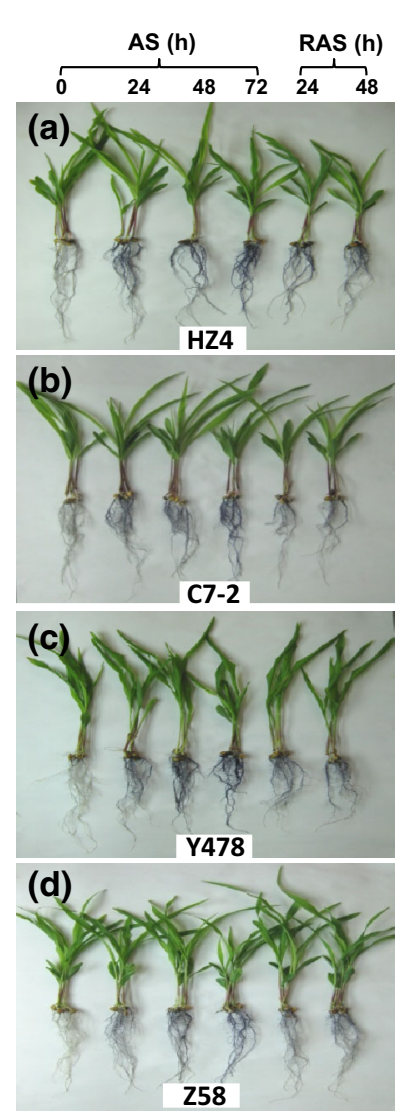

(e)

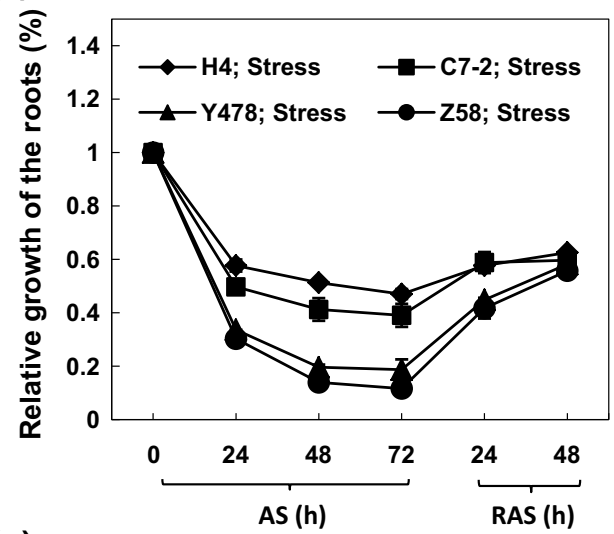

(g)

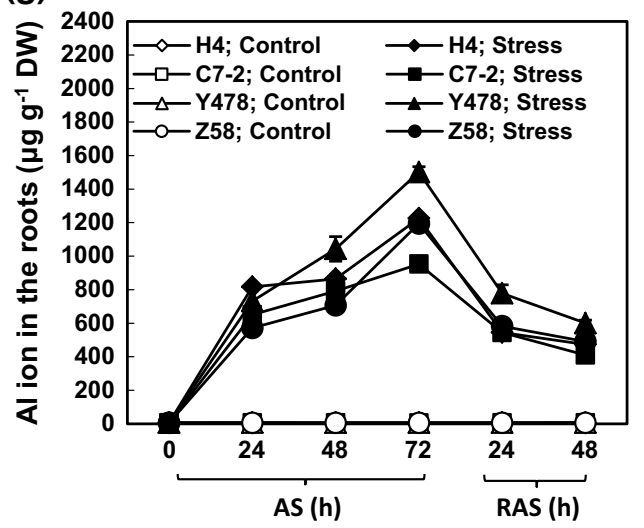

(f)

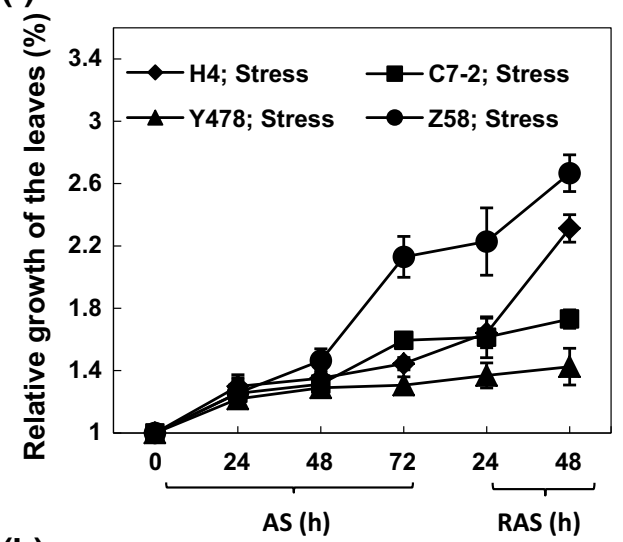

(h)



Fig. 1 The growth of maize seedlings under AS and after RAS. The phenotypes of the different maize lines $(\mathbf{a}-\mathbf{d})$, the relative growth of roots (e) and leaves (f), and the $\mathrm{Al}$ ion contents in roots ( $\mathbf{g})$ and leaves

The decreased activity levels of SOD and POD in the roots and leaves of all of the AS-treated maize lines (Fig. 2a-d) were not in agreement with the results previously reported in maize under AS (Boscolo et al. 2003).

\section{Change in CAT activity}

The CAT activity levels in the roots of the AS-treated maize lines started to significantly decrease $24 \mathrm{~h}$ after AS, and then remained almost unchanged during further AS treatment (Fig. 2e). After RAS, the activity levels significantly increased but did not reach the activity levels in the respective control roots (Fig. 2e). During AS and RAS, the changes in the CAT activity levels in the leaves of the AStreated maize lines (Fig. 2f) were similar to the changes in SOD activity levels in the leaves of the AS-treated maize lines (Fig. 2b).

\section{MDA content and SOR production}

The MAD contents in the roots of the AS-treated maize lines started to significantly increase $24 \mathrm{~h}$ after AS (h). The values are mean \pm standard error (SE) from at least five individual seedlings

(Fig. 3a). After the RAS treatment, the contents in the roots of the AS-treated maize lines significantly declined when compared with those of the respective roots at the 72-h time point of AS. However, only the MDA content in the roots of the AS-treated Z58 line was similar to that in the corresponding control after RAS treatment (Fig. 3a).

The MDA contents in the leaves of the AS-treated maize lines started to significantly increase $48 \mathrm{~h}$ after AS (Fig. 3b), lagging behind the changes in the MDA contents in the roots of the AS-treated maize lines (Fig. 3a). However, the MDA contents in the leaves of the 72-h-stressed maize lines almost recovered after RAS treatment to the respective control level (Fig. 3b).

The increased MDA contents in the roots and leaves of the AS-treated maize lines did not support the previous conclusion that the presence of $\mathrm{Al}$ did not cause lipid peroxidation (Boscolo et al. 2003).

With the increase in MDA contents, SOR production in the roots and leaves of all the AS-treated maize lines increased at $24 \mathrm{~h}$, decreased at $48 \mathrm{~h}$, and then increased again at $72 \mathrm{~h}$ after AS (Fig. 3c, d). 

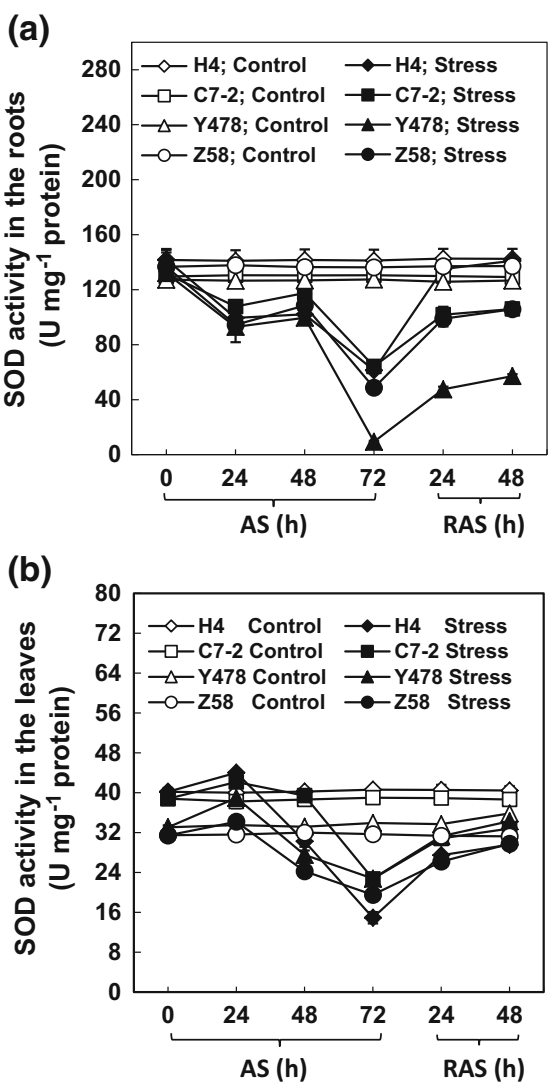

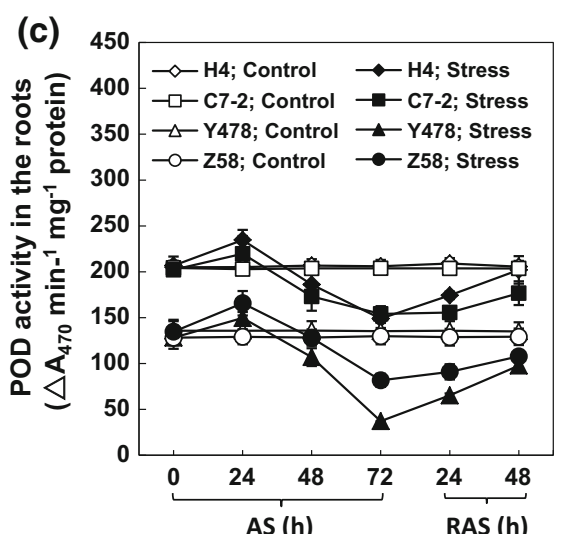

(d)

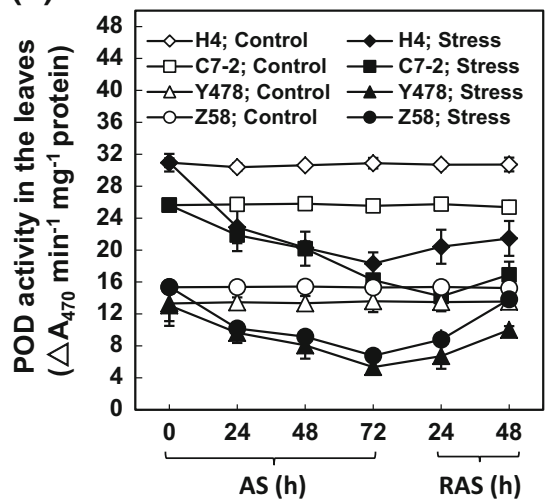

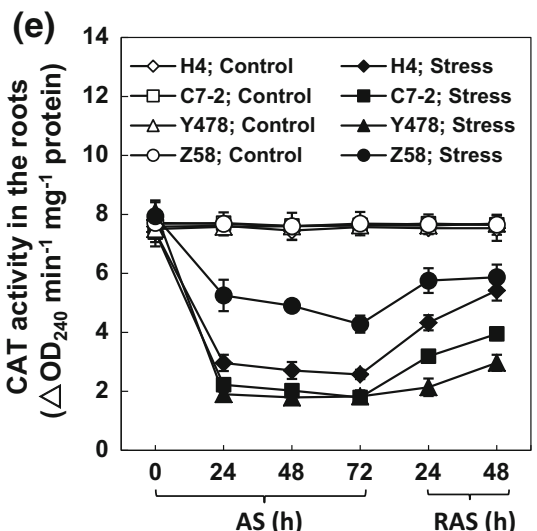

(f)

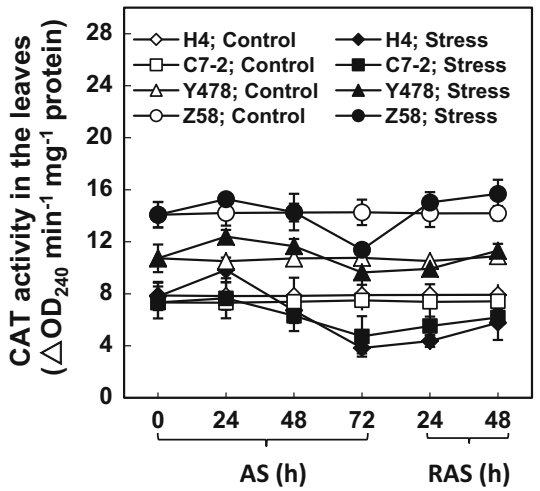

Fig. 2 Activities of antioxidant enzymes in the maize tissues under AS and after RAS. The SOD activities in roots (a) and leaves (b), the POD activities in roots (c) and leaves (d), and the CAT activities in roots (e) and leaves (f). The values are mean \pm SE from at least five individual seedlings

\section{Viability of the root cells}

The Evans blue staining indicated that decreased root cell viability under AS occurred in cells near the root tips at $24 \mathrm{~h}$ after AS, and then was found in the cells in the upper tissues with AS, being more obvious in the roots of the AS-treated $\mathrm{H} 4$ and C7-2 lines (Fig. 4). Notably, a decreased root cell viability in Z58 line during AS seemed to be limited to the cells near the root tip zone (Fig. 4). The decrease in root cell viability in the AStreated maize lines could be alleviated by RAS treatment, especially in the roots of AS-treated Y478 and Z58 lines (Fig. 4).

The cells in the root tip zones of the AS-treated maize lines showed plasmolysis and cell wall rupture, and had concentrated and enlarged nuclei, while the cellular contents leaked (Fig. 4). These symptoms started $48 \mathrm{~h}$ after AS, and were more serious in $\mathrm{H} 4, \mathrm{C} 7-2$ and Y478 lines than in Z58 line (Fig. 4). Interestingly, the symptoms were greatly alleviated by $48 \mathrm{~h}$ of RAS treatment (Fig. 4).

\section{$\mathrm{K}, \mathrm{Ca}$, and $\mathrm{Mg}$ ions in the tissues}

The $\mathrm{K}, \mathrm{Ca}$, and $\mathrm{Mg}$ ion contents in the roots and leaves of all the AS-treated maize lines declined when compared with the levels in the respective controls (Fig. 5a-f). The contents of these ions in tissues of the AS-treated maize lines were significantly enhanced by RAS treatment (Fig. 5a-f). These results echoed the changes in cell structure in the root tip zone (Fig. 4).

\section{Protein and chlorophyll contents, and the photosynthetic rate}

The total protein contents were significantly higher in the roots and leaves of the AS-treated maize lines than in the roots and leaves of respective control lines (Fig. 6a, b). The protein content started to significantly increase $24 \mathrm{~h}$ after AS in the roots (Fig. 6a) and $48 \mathrm{~h}$ after AS in the leaves (Fig. 6b). After RAS treatment, the protein contents in the tissues of the AS-treated maize lines significantly declined 
(a)

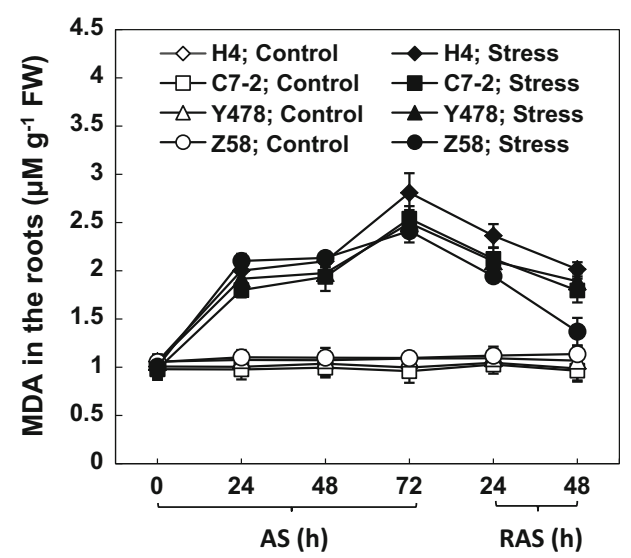

(b)

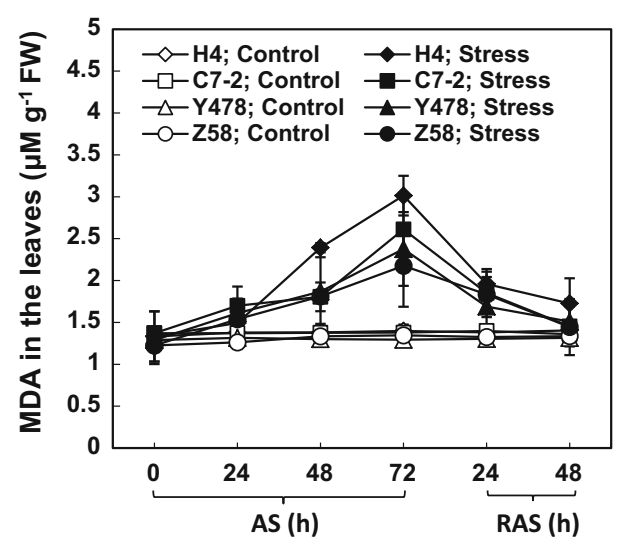

(c)

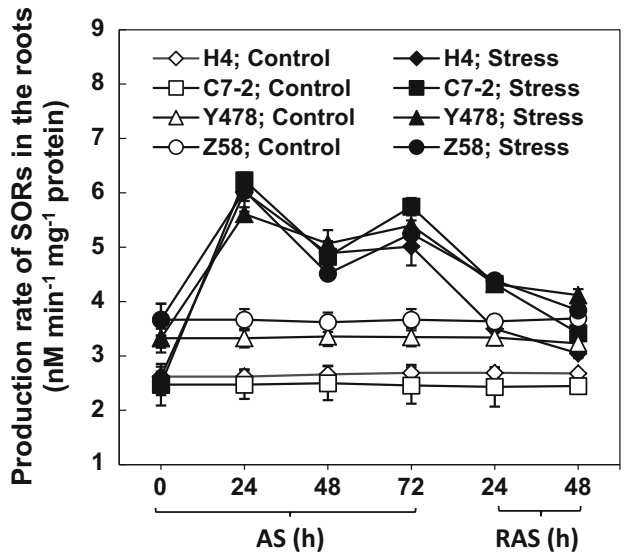

(d)

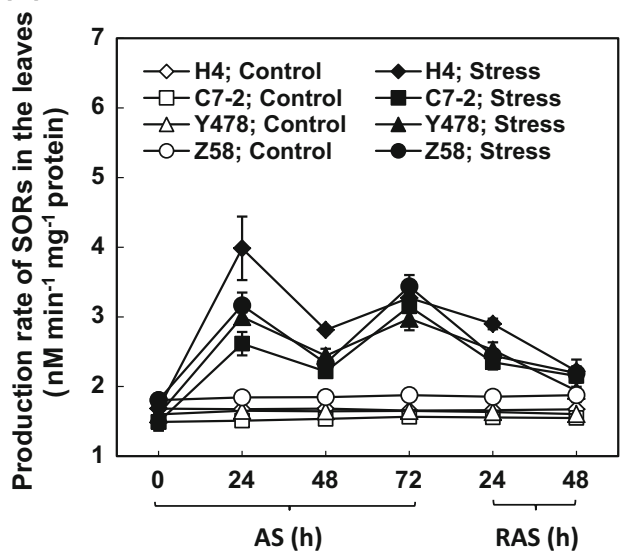

Fig. 3 The MAD contents, and SOR production rate in the maize tissues under AS and after RAS. The MDA contents in roots (a) and leaves (b). The SOR production rates in roots (c) and leaves (d). The values are mean \pm SE from at least five individual seedlings

when compared with protein content levels in corresponding AS-treated maize lines before RAS (Fig. 6a, b).

The chlorophyll contents in the leaves of the AS-treated Z58 line decreased slightly within $48 \mathrm{~h}$ of AS and significantly $72 \mathrm{~h}$ after AS when compared with the chlorophyll levels in the control line (Fig. 6c). A significant decrease in the chlorophyll content was found in three AS-treated maize lines (H4, C7-2 and Y478), starting $24 \mathrm{~h}$ or $48 \mathrm{~h}$ after AS depending on the lines. After RAS treatment, the chlorophyll contents in the leaves of the AS-treated maize lines reached the levels in the respective controls (Fig. 6c).

The photosynthetic rates in the leaves of all the AStreated maize lines started to significantly decrease $24 \mathrm{~h}$ after AS (Fig. 6d). After RAS treatment, the photosynthetic rates in the leaves of the AS-treated maize lines obviously increased when compared with the photosynthetic rate levels in respective maize lines treated by AS for $72 \mathrm{~h}$ (Fig. 6d).

\section{Discussion}

Al toxicity in plants occurs in acidic soils (Matsumoto 2000). However, the beneficial effects of low $\mathrm{Al}$ doses on plants in acidic soils may occur in both Al-tolerant plants and many Al-stimulated plants (Osaki et al. 1997), and is characterized by growth promotion. The seedlings of Altolerant triticale and alfalfa showed large root regrowth during AS (Zhang et al. 1999, 2007). Additionally, lower Al concentrations significantly stimulated the root growth of Al-tolerant soybean PI 416937 (Du et al. 2010).

All of the maize lines tested in this study showed similar changes in leaf and root growth rates, root cell viability, SOD, POD, and CAT activities, of $\mathrm{K}, \mathrm{Ca}$ and $\mathrm{Mg}$ ion contents, protein contents, chlorophyll and MDA contents, and photosynthetic rates under AS and after RAS, but the magnitudes and response time of the changes differed depending on the maize line, suggesting differences in AS- 


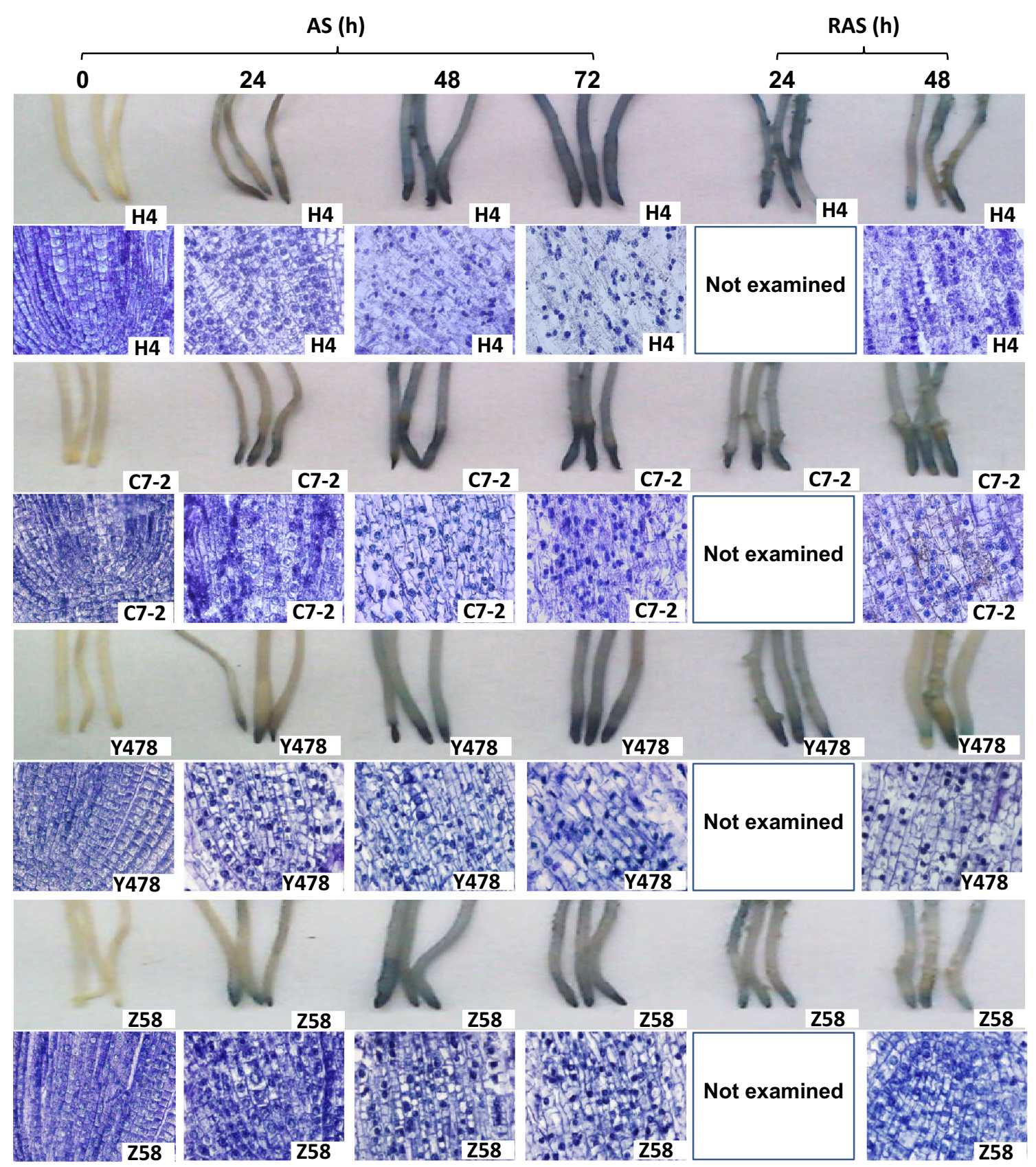

Fig. 4 Viability and structure of the fresh root cells under AS and after RAS. The root cell viability was assayed by using Evans blue staining method. For observation of cell structure, the tissues of the

tolerant mechanisms. The increased MAD contents in the tissues of the AS-treated maize lines (Fig. 3a, b) indirectly supported the previous conclusion that the $\mathrm{Al}$ treatment could trigger lipid peroxidation in the sensitive maize lines (Giannakoula et al. 2008), but they did not corroborate the view that $\mathrm{Al}$ treatments did not induce lipid peroxidation in both sensitive and tolerant maize lines (Boscolo et al. 2003). Our results showed that in maize, AS can cause decreases in the $\mathrm{Ca}$ and $\mathrm{Mg}$ ion contents in Al-tolerant root tip zone were sectioned lengthwise by using a paraffin slicing machine and then photographed by light microscopy. The detailed procedures were indicated in "Materials and methods"

Y478 and $\mathrm{Z} 58$ lines and $\mathrm{Al}$-sensitive $\mathrm{H} 4$ and $\mathrm{C} 7-2$ lines (Fig. 5c-f), which supported previous conclusions (Giannakoula et al. 2008; Mihailovic et al. 2008). However, AS caused a significant decrease in $\mathrm{K}$ ion contents (Fig. 5a, b), which was in contrast to the previous conclusion ( $\mathrm{Yu}$ et al. 2011). The discrepancies in the above-mentioned results likely resulted from the differences among the maize lines and/or partly from the experimental conditions, such as applied $\mathrm{Al}^{3+}$ concentrations and/or stress duration. During 
(a)

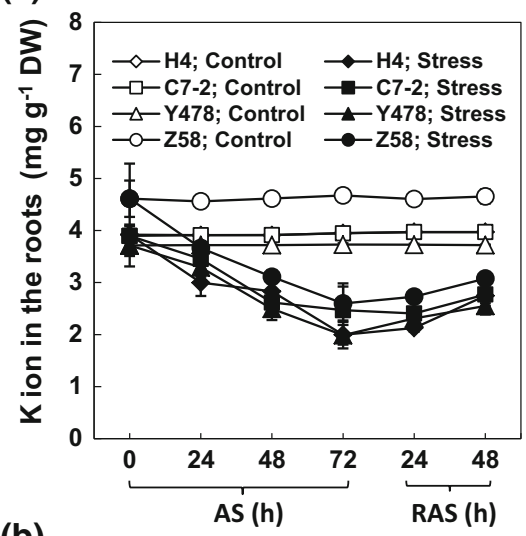

(b)

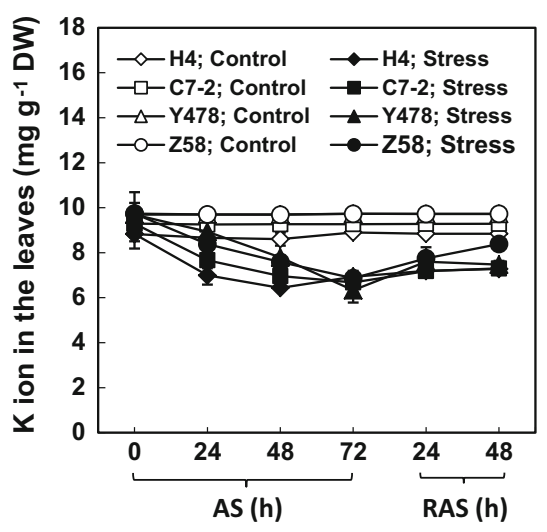

(c)

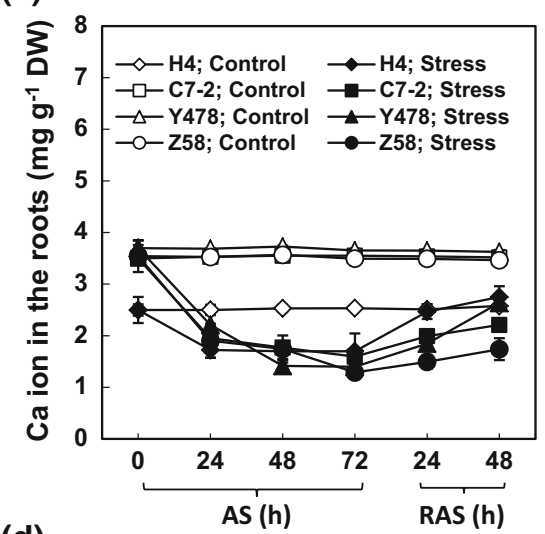

(d)

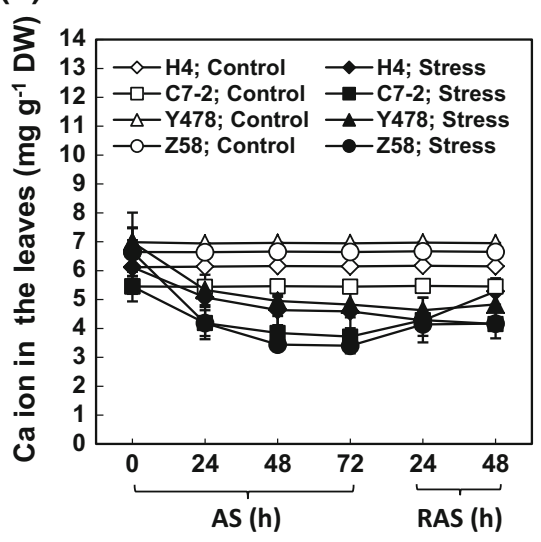

(e)

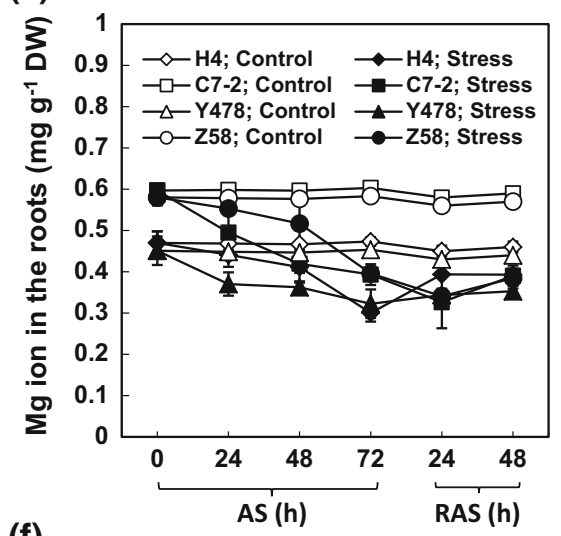

(f)

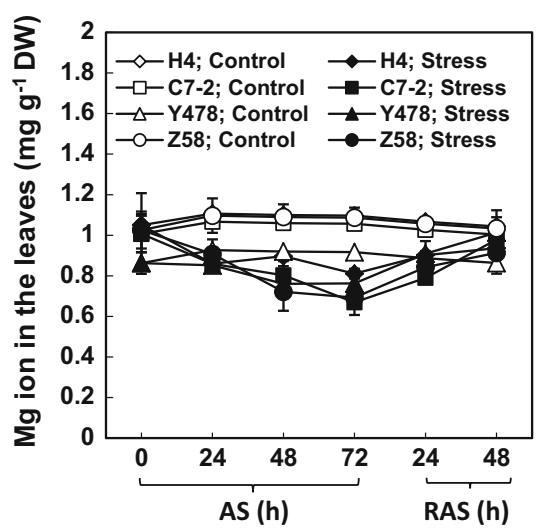

Fig. 5 The contents of $\mathrm{K}(\mathbf{a}, \mathbf{b}), \mathrm{Ca}(\mathbf{c}, \mathbf{d})$ and Mg ions $(\mathbf{e}, \mathbf{f})$ in maize roots $(\mathbf{a}, \mathbf{c}, \mathbf{e})$ and leaves $(\mathbf{b}, \mathbf{d}, \mathbf{f})$ under AS and after RAS. The values are mean \pm SE from at least five individual seedlings

AS or after RAS, changes in the contents of $\mathrm{Ca}, \mathrm{Mg}$ and $\mathrm{K}$ ions (Fig. 5) were closely related to changes in the cell structure in the root tip zone (Fig. 4), suggesting that low external $\mathrm{Al}$ concentrations can also lead to the loss of $\mathrm{Ca}$, $\mathrm{Mg}$, and $\mathrm{K}$ ions by disrupting the cell's integrity. Additionally, the decreased ion contents in the roots of the AStreated maize lines may be partially ascribed to impaired root uptake capacity during AS.

Considering the promotion of leaf growth (Fig. 1a-c) during AS as well as the recovery of AS-damaged cell walls in the root tip zone after RAS (Fig. 4) and other parameters of AS-treated maize lines after RAS treatment, we conclude that low doses of $\mathrm{Al}$ only decrease root growth rate and that the AS-caused inhibition of root growth of maize can be alleviated by appropriate RAS treatments.

For AS-treated maize lines, changes in the chlorophyll contents (Fig. 6c) did not correspond with changes in the photosynthetic rates (Fig. 6d), suggesting that the differences among photosynthetic rates in maize lines under AS result from differences in photosystems rather than chlorophyll contents. This reasoning partly confirms a previous finding that AS led to a severe decrease in activity of photosystem 2 activity (Mihailovic et al. 2008).

For an in-depth analysis of the correlation among the parameters, we conducted a multiple factor correlation analysis of the data resulting from AS and RAS treatments (Tables 1, 2).

SODs together with PODs form the first line of antioxidant defense against ROS (Ito-kuwa et al. 1999; Veljovic-Jovanovic et al. 2006). In the SOD-POD system, SODs first degrade $\mathrm{O}_{2}^{-1}$ into $\mathrm{O}_{2}$ and $\mathrm{H}_{2} \mathrm{O}_{2}$, and the latter is then degraded by POD into $\mathrm{H}_{2} \mathrm{O}$ and $\mathrm{O}_{2}$ (Boscolo et al. 2003; Wang et al. 2013). CAT scavenges photorespiratory $\mathrm{H}_{2} \mathrm{O}_{2}$ by a catalytic reaction of $2 \mathrm{H}_{2} \mathrm{O}_{2} \rightarrow \mathrm{O}_{2}+2 \mathrm{H}_{2} \mathrm{O}$ (Willekens et al. 1997). As expected, there was a positive correlation between SOD and POD activities in the roots (Table 1) and leaves (Table 2) of AS-treated maize lines. Interestingly, the CAT activity showed a positive correlation with the SOD activity in the roots of the AS-treated maize lines (Table 1) but showed a negative correlation with the POD activity in the leaves of the AS-treated maize lines (Table 2). This suggests that the roots of the AStreated maize lines require more antioxidant enzymes to 
Fig. 6 The protein content in maize roots (a) and leaves (b), and chlorophyll contents (c) and photosynthetic rate (d) in maize leaves under AS and after RAS.

The values are mean \pm SE from at least five individual seedlings (a)

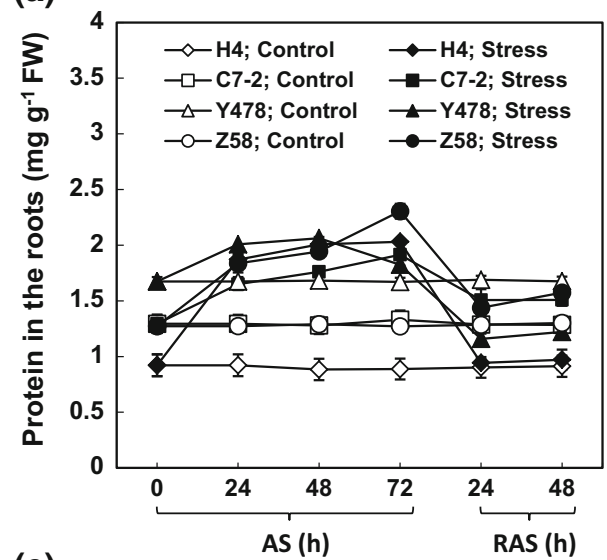

(c)

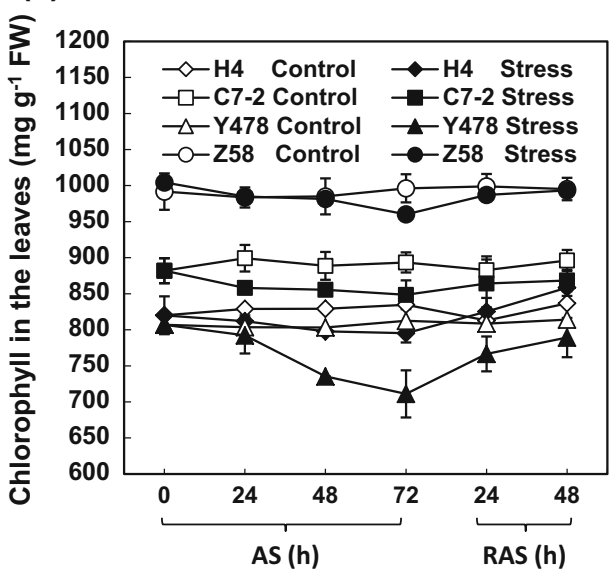

(b)

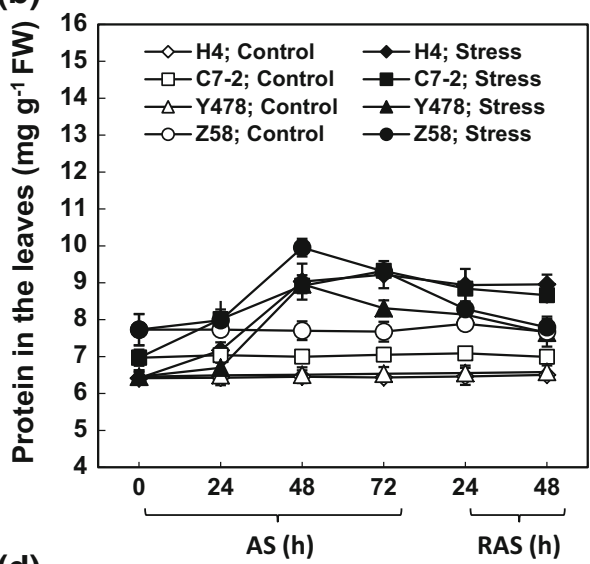

(d)

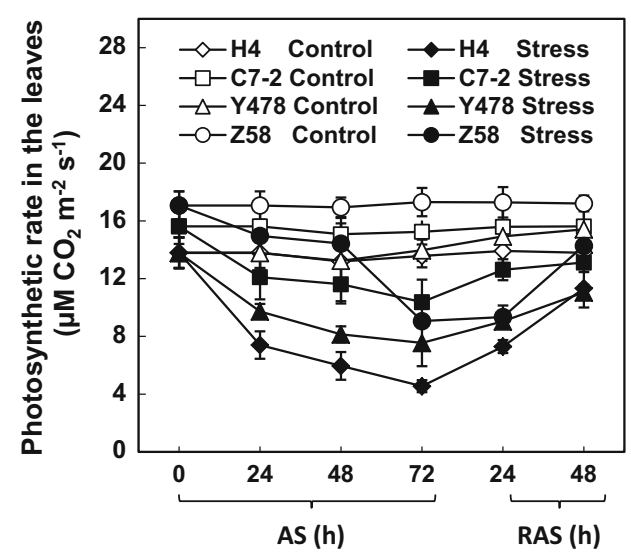

Table 1 Correlation among affected parameters in the roots under AS and after RAS

\begin{tabular}{|c|c|c|c|c|c|c|c|c|c|c|c|}
\hline Parameters & $\mathrm{Al}$ & Growth & SOD & POD & CAT & SOR & MDA & Protein & K & $\mathrm{Ca}$ & $\mathrm{Mg}$ \\
\hline $\mathrm{Al}$ & 1 & & & & & & & & & & \\
\hline Growth & $-0.873 * *$ & 1 & & & & & & & & & \\
\hline SOD & $-0.798 *$ & 0.664 & 1 & & & & & & & & \\
\hline POD & -0.414 & 0.457 & $0.767 *$ & 1 & & & & & & & \\
\hline CAT & $-0.808 *$ & $0.740 *$ & $0.725^{*}$ & 0.140 & 1 & & & & & & \\
\hline SOR & $0.711^{*}$ & $-0.711^{*}$ & $-0.754^{*}$ & -0.090 & $-0.798 *$ & 1 & & & & & \\
\hline MDA & $0.869 * *$ & $-0.785^{*}$ & $-0.749 *$ & -0.240 & $-0.747 *$ & $0.708 *$ & 1 & & & & \\
\hline Protein & $0.745^{*}$ & -0.623 & -0.453 & -0.187 & -0.453 & $0.730 *$ & 0.442 & 1 & & & \\
\hline K & $-0.766^{*}$ & 0.639 & 0.610 & 0.372 & $0.716^{*}$ & -0.276 & $-0.833 *$ & -0.194 & 1 & & \\
\hline $\mathrm{Ca}$ & $-0.832 *$ & $0.849 *$ & 0.595 & 0.281 & 0.695 & -0.672 & $-0.741^{*}$ & -0.559 & 0.650 & 1 & \\
\hline $\mathrm{Mg}$ & $-0.703 *$ & 0.463 & 0.553 & 0.453 & 0.594 & -0.177 & $-0.605^{*}$ & -0.127 & $0.849 *$ & 0.535 & 1 \\
\hline
\end{tabular}

The analysis was conducted with all the data resulting from four the roots of Chinese maize foundation genotypes H4, C7-2, Y478 and Z58 under AS and after RAS according to Pearson correlation coefficients

$* P<0.05 ; * * P<0.01$

cope with AS-triggered peroxidation relative to the AStreated leaves. This appears reasonable because SOR production was greater in the AS-treated roots than in the AStreated leaves (Fig. 3c, d). Thus, CAT is likely an auxiliary antioxidant enzyme that selectively cooperates with either
SOD or POD to play a role in antioxidation under AS and after RAS, depending on maize tissues.

The CAT activity positively correlated with root growth rate (Table 1), while the SOD activity showed a positive correlation with the leaf growth rate (Table 2). This 


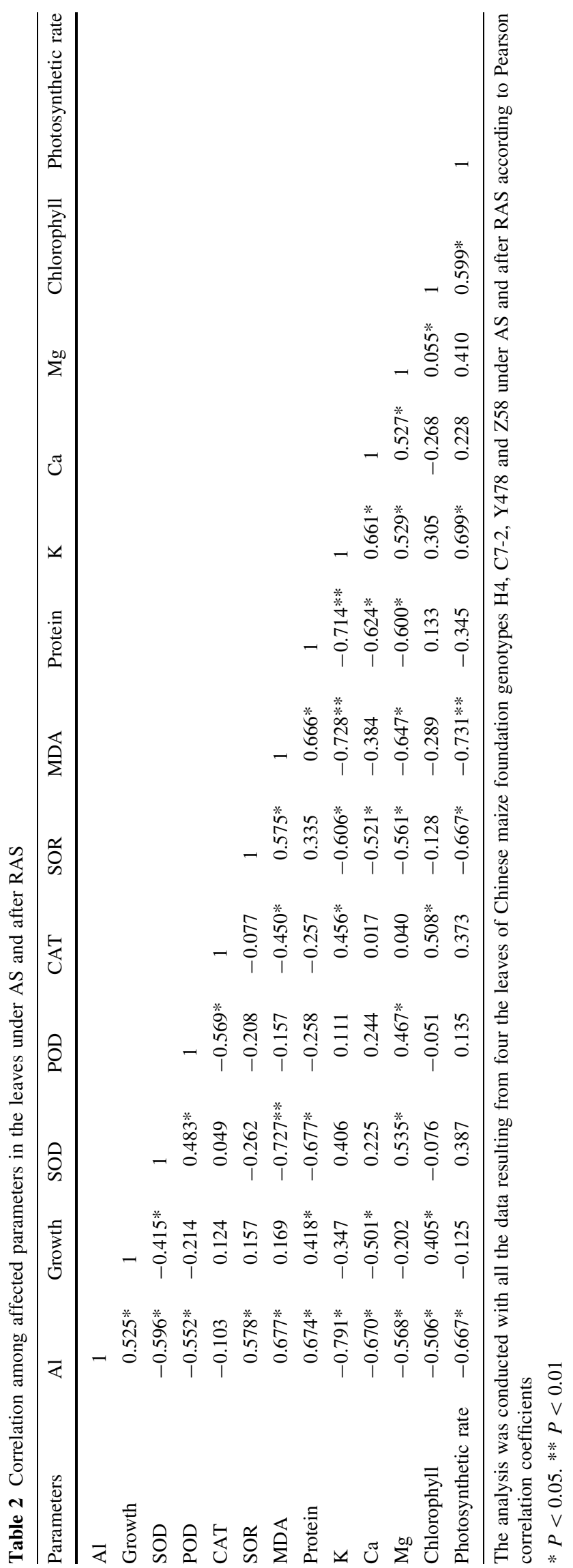

suggests that CAT is a major antioxidant enzyme responsible for root growth, and that SOD is an important enzyme for leaf growth under AS and after RAS.

There was a strong correlation between the $\mathrm{Mg}$ ion content and $\mathrm{K}$ ion content in the roots of the AS-treated maize lines (Table 1), and among $\mathrm{Ca}, \mathrm{K}$, and $\mathrm{Mg}$ ion contents in the leaves of the AS-treated maize lines (Table 2). This strongly suggests that there is a synergetic leakage from and/or uptake of $\mathrm{Ca}, \mathrm{K}$, and $\mathrm{Mg}$ ions by the roots under AS, depending on the maize tissues. The chlorophyll content positively correlated with the $\mathrm{Mg}$ ion content, but the photosynthetic rate positively correlated with the $\mathrm{K}$ ion content in the leaves of the AS-treated maize lines (Table 2), indicating differential differences in roles of $\mathrm{Mg}$ and $\mathrm{K}$ ions in photosynthesis under $\mathrm{AS}$ and during RAS.

The promotion of leaf growth in the AS-treated maize lines not only occurred during AS but also lasted during RAS (Fig. 1f), suggesting that the AS-promoting effect on leaf growth is in the 'memory' of AS-treated maize. Reportedly, the growth stimulation in plants receiving $\mathrm{Al}$ applications was ascribed not only to the alleviation of $\mathrm{H}^{+}$ toxicity but also to the increase in root uptake activity of nutrient elements, such as P (Osaki et al. 1997). However, this conclusion was not supported by the research in which the soybean roots were exposed to $\mathrm{Al}$ in a $0.5 \mathrm{mM} \mathrm{Ca}$ solution at $\mathrm{pH} 4.5$ without other nutrients (Du et al. 2010). In the Al-accumulating plant Mel. malabathricum, Al, together with other nutrients, could promote the synthesis of adequate amounts of citrate (Watanabe et al. 2005) and could also induce a reduction in toxic $\mathrm{Fe}$ accumulation in roots and shoots (Watanabe et al. 2006). Therefore, the exact mechanisms for the AS-promoting effect on plant growth are still not fully understood (Ma 2007). The analyses indicated that AS-promoted leaf growth correlated positively to protein content and negatively to $\mathrm{Ca}$ ion content (Table 2). An increased protein content is undoubtedly conducive to plant growth at least because proteins are important "raw materials" (precursors) for important metabolites such as amino acids. Although the $\mathrm{Ca}$ ion content in roots and leaves of the AS-treated maize lines decreased (Fig. 5c, d), it correlated positively with root growth (Table 1) and negatively with AS-promoted leaf growth (Table 2). These results supported the conclusion that elevating $\mathrm{Ca}$ inhibits shoot growth and promotes root growth (Hepler 2005). This may be because reducing the $\mathrm{Ca}$ ion concentration promotes cell and tissue elongation and elevating $\mathrm{Ca}$ ion inhibits cytoplasmic streaming (Hepler 2005). The stresses, to some extent, lead to ubiquitin-mediated proteasomal degradation of growthrepressing proteins, such as DELLA in plants and consequently promote growth (Conti et al. 2014). Therefore, another reason for AS-promoted leaf growth is also likely 
associated with the discharge of growth-inhibitory factors from the growth-regulating molecules under AS.

\section{Conclusion}

Low doses of $\mathrm{Al}$ inhibit root growth but enhance leaf growth in maize lines. The AS-promoted leaf growth is likely associated with increased protein synthesis, a lowered $\mathrm{Ca}$ ion content, and the discharge of growth-inhibitory factors from the growth-regulating molecules. Some unknown compensating mechanisms regulate AS-promoted leaf growth. Additionally, AS-promoted leaf growth is in the 'memory' of AS-treated maize plants. CAT is an auxiliary antioxidant enzyme that work selectively with either SOD or POD against AS-caused peroxidation. CAT is a major antioxidant enzyme responsible for root growth, but SOD is important for leaf growth under AS and during RAS.

Author contribution statement L.W. conducted all experiments; X.-W.F. assisted in the design of some of the experiment programs and participated in discussion of the results; J.-L.P. and Z.-B.H. helped L.W. perform parts of the experiments; Y.-Z.L. was in charge of the research project and finished the manuscript.

Acknowledgments We are grateful to Prof. Yu Li (The Institute of Crop Sciences, CAAS) who supplied the maize seeds.

\section{Compliance with ethical standards}

Conflict of interest We state no conflict of interest with others.

Ethical statement Our work complies to the ethical rules applicable for this journal.

Open Access This article is distributed under the terms of the Creative Commons Attribution 4.0 International License (http://crea tivecommons.org/licenses/by/4.0/), which permits unrestricted use, distribution, and reproduction in any medium, provided you give appropriate credit to the original author(s) and the source, provide a link to the Creative Commons license, and indicate if changes were made.

\section{References}

Boscolo PRS, Menossi M, Jorge RA (2003) Aluminum-induced oxidative stress in maize. Phytochemistry 62:181-189

Cakmak I, Horst WJ (1991) Effect of aluminium on lipid peroxidation, superoxide dismutase, catalase, and peroxidase activities in root tips of soybean (Glycine max). Physiol Plant 83:463-468

Chen LS (2006) Physiological responses and tolerance of plant shoot to aluminum toxicity. J Plant Physiol Mol Biol 32:143-155

Čiamporová M (2002) Morphological and structural response of plant roots to aluminium at organ, tissue, and cellular levels. Biol Plant 45:161-171
Conti L, Nelis S, Zhang C, Woodcock A, Swarup R, Galbiati M, Tonelli C, Napier R, Hedden P, Bennett M, Sadanandom A (2014) Small ubiquitin-like modifier protein SUMO enables plants to control growth independently of the phytohormone gibberellins. Dev Cell 28:102-110

Doncheva S, Amenós M, Poschenrieder C, Barceló J (2005) Root cell patterning: a primary target for aluminium toxicity in maize. J Exp Bot 56:1213-1220

Du B, Nian H, Zhang Z, Yang C (2010) Effects of aluminum on superoxide dismutase and peroxidase activities, and lipid peroxidation in the roots and calluses of soybeans differing in aluminum tolerance. Acta Physiol Plant 32:883-890

Ghanati F, Morita A, Yokota H (2005) Effects of aluminium on the growth of tea plant and activation of antioxidant system. Plant Soil 276:133-141

Giannakoula A, Moustakas M, Mylona P, Papadakis I, Yupsanis T (2008) Aluminum tolerance in maize is correlated with increased levels of mineral nutrients, carbohydrates and proline, and decreased levels of lipid peroxidation and $\mathrm{Al}$ accumulation. J Plant Physiol 165:385-396

Giannakoula A, Moustakas M, Syros T, Yupsanis T (2010) Aluminum stress induces up-regulation of an efficient antioxidant system in the Al-tolerant maize line but not in the Alsensitive line. Environ Exp Bot 67:487-494

$\mathrm{He} \mathrm{H,} \mathrm{He} \mathrm{L,} \mathrm{Gu} \mathrm{M} \mathrm{(2014)} \mathrm{Role} \mathrm{of} \mathrm{microRNAs} \mathrm{in} \mathrm{aluminum} \mathrm{stress} \mathrm{in}$ plants. Plant Cell Rep 33:831-836

Hepler PK (2005) Calcium: a central regulator of plant growth and development. Plant Cell 17:2142-2155

Holmström SJM, van Hees PAW, Lundström US (2005) Modelling of aluminium chemistry in soil solution of untreated and dolomite treated podzolic soil. Geoderma 127:280-292

Illéš P, Schlicht M, Pavlovkin J, Lichtscheidl I, Baluška F, Ovečka M (2006) Aluminium toxicity in plants: internalization of aluminium into cells of the transition zone in Arabidopsis root apices related to changes in plasma membrane potential, endosomal behaviour, and nitric oxide production. J Exp Bot 57:4201-4213

Inostroza-Blancheteau C, Rengel Z, Alberdi M, de la Luz Mora M, Aquea F, Arce-Johnson P, Reyes-Díaz M (2012) Molecular and physiological strategies to increase aluminum resistance in plants. Mol Biol Rep 39:2069-2079

Ito-kuwa S, Nakamura K, Aoki S, Osafune T, Vidotto V, Pienthaweechai K (1999) Oxidative stress sensitivity and superoxide dismutase of a wild-type parent strain and a respiratory mutant of Candida albicans. Med Mycol 37:307-314

Kochian LV (1995) Cellular mechanisms of aluminum toxicity and resistance in plants. Annu Rev Plant Physiol Plant Mol Bioi 46:237-260

Ma JF (2000) Role of organic acids in detoxification of aluminum in higher plants. Plant Cell Physiol 41:383-390

Ma JF (2007) Syndrome of aluminum toxicity and diversity of aluminum resistance in higher plants. Int Rev Cytol 264:225-252

Ma JF, Furukawa J (2003) Recent progress in the research of external Al detoxification in higher plants: a minireview. J Inorg Biochem 97:46-51

Matsumoto H (2000) Cell biology of aluminum toxicity and tolerance in higher plants. Int Rev Cytol 200:1-46

Mihailovic I, Drazic G, Vucinic Z (2008) Effects of aluminium on photosynthetic performance in Al-sensitive and Al-tolerant maize inbred lines. Photosynthetica 46:476-480

Mossor-Pietraszewska T (2001) Effect of aluminium on plant growth and metabolism. Acta Biochim Pol 48:673-686

Osaki M, Watanabe T, Tandano T (1997) Beneficial effect of aluminum on growth of plants adapted to low $\mathrm{pH}$ soils. Soil Sci Plant 43:551-563 
Panda SK, Baluska F, Matsumoto H (2009) Aluminum stress signaling in plants. Plant Signal Beh 4:592-597

Pilon-Smits EA, Quinn CF, Tapken W, Malagoli M, Schiavon M (2009) Physiological functions of beneficial elements. Curr Opin Plant Biol 12:267-274

Poschenrieder C, Gunsé B, Corrales I, Barceló J (2008) A glance into aluminum toxicity and resistance in plants. Sci Total Environ 400:356-368

Sivaguru M, Fujiwara T, Samaj J, Baluska F, Yang Z, Osawa H, Maeda T, Mori T, Volkmann D, Matsumoto H (2000) Aluminum-induced $1 \rightarrow 3-\beta-D$-glucan inhibits cell-to-cell trafficking of molecules through plasmodesmata. A new mechanism of aluminum toxicity in plants. Plant Physiol 124:991-1006

Tamás L, Budíková S, Šimonovičová M, Huttová J, Široká B, Mistrík I (2006) Rapid and simple method for Al-toxicity analysis in emerging barley roots during germination. Biol Plant 50:87-93

Tang ZC (1999) Modern plant physiology laboratory manual. Science Press, Beijing

Veljovic-Jovanovic S, Kukavica B, Stevanovic B, Navari-Izzo F (2006) Senescence- and drought-related changes in peroxidase and superoxide dismutase isoforms in leaves of Ramonda serbica. J Exp Bot 57:1759-1768

Wang H, Xu R, You L, Zhong G (2013) Characterization of Cutolerant bacteria and definition of their role in promotion of growth, $\mathrm{Cu}$ accumulation and reduction of $\mathrm{Cu}$ toxicity in Triticum aestivum L. Ecotoxicol Environ Saf 94:1-7

Watanabe T, Jansen S, Osaki M (2005) The beneficial effect of aluminium and the role of citrate in $\mathrm{Al}$ accumulation in Melastoma malabathricum. New Phytol 165:773-780

Watanabe T, Jansen S, Osaki M (2006) Al-Fe interactions and growth enhancement in Melastoma malabathricum and Miscanthus sinensis dominating acid sulphate soils. Plant Cell Environ 29:2124-2132

Willekens H, Chamnongpol S, Davey M, Schraudner M, Langebartels C, Van Montagu M, Inzé D, Van Camp W (1997) Catalase is a sink for $\mathrm{H}_{2} \mathrm{O}_{2}$ and is indispensable for stress defence in $\mathrm{C}_{3}$ plants. EMBO J 16:4806-4816

Yoshii Y (1937) Aluminium requirements of Solfatara plants. Bot Magazine 51:262-270

Yu HN, Liu P, Wang ZY, Chen WR, Xu GD (2011) The effect of aluminum treatments on the root growth and cell ultrastructure of two soybean genotypes. Crop Prot 30:323-328

Zhang X, Jessop RS, Ellison F (1999) Inheritance of root regrowth as an indicator of apparent aluminum tolerance in triticale. Euphytica 108:97-103

Zhang X, Humphries A, Auricht G (2007) Genetic variability and inheritance of aluminium tolerance as indicated by long root regrowth in lucerne (Medicago sativa L.). Euphytica 157:177-184 